\title{
Inhibition of Toothpaste Denture Cleanser Rosella Petals Have Stored Several Times on Denture Plaque Formation, Colonies of Bacteria and Candida Albicans
}

\author{
Muh. Akira Takashi ${ }^{1 *}$, Moh. Dharmautama ${ }^{2}$, Bahruddin Thalib $^{2}$ \\ ${ }^{1}$ Student of Faculty of Dentistry, Faculty of Dentistry, Hasanuddin University, Makassar, Indonesia \\ 2. Lecturer of Faculty of Dentistry, Faculty of Dentistry, Hasanuddin University, Makassar, Indonesia
}

*E-mail: muhakira@gmail.com

\begin{abstract}
Objective: It is known the benefits of rosella flower petals are able to inhibit the growth of bacteria and C. albicans. In addition, do not change the color and transverse strength dentures plate. Unknown inhibitory power after being stored several times in the form of toothpaste.

Methods: This is a clinical and laboratory experimental research, with pre-and post-test design. The effectiveness of roselle denture cleanser toothpaste was assessed on 5 samples 3, 6 and 9 months after they were created. Plaque score was assessed by the Modified Quigley Hein index, colonization of bacteria and C.albicans were assessed through laboratory observations. Data were analyzed using Wilcoxon and Friedman two ways.

Result: The result show that there were changes in the effectiveness of roselle denture cleanser toothpaste in inhibiting the growth of bacteria and Candida in the $9^{\text {th }}$ month, but no change of effectiveness in inhibiting plaque formation.

Conclusion: It was concluded that the effectiveness of roselle denture toothpaste in inhibiting the growth of bacteria and Candida has decreased; but the same cleanser paste is still effective in inhibiting plaque formation after 9-month storage.
\end{abstract}

Keywords: bacteria,Candida albicans, denture plaque, roselle denture toothpaste

\section{Introduction}

Partial or total tooth loss is not only experienced by elderly but also by younger people. Although there are many causes of tooth loss, tooth caries and periodontal disease are considered as two main factors of tooth loss.

There are many choices of dentures to replace missing teeth, from removable to fixed denture. Conventional heat cured acrylic removable denture remains commonly used by dentist. In addition, having a number of advantages, it also has drawbacks. Generally, acrylic surface facing mucosal tissue (intaglio) hasmicro-pit and micro porosity which can become a microorganism reservoir known as denture plaque. This microorganism accumulation is difficult to remove. ${ }^{2}$

Denture plaque is a layer of microorganism and its heterogeneous metabolites and consists of $10^{11}$ organisms/g. Denture plaque formation starts from attachment, aggretion, and microbes' growth. Plaque accumulation generally occurs in an area that is not exposed to salivary flow and mechanical force in mouth which can cleanse the plaque. These areas are commonly seen in denture.

Microflora that can be cultured from denture plaque are Streptococcus spp. (S.sanguinis mainly S.oralis, S.anginosus, S.salivarius), Staphylococcus spp. (S.aureus, S.epidermidis), Gram-positive rod-shaped bacteria (Actinomyces spp. [A.israelii, A.naeslundii, A.odontolyticus], Lactobacillus, Propionibacterium spp.), Veillonella spp., Gram-negative rod-shape bacteria and fungi (Candida albicans). If Streptococcus mutants is not found as the dominant microbial species in denture plaque, this can be an important sign because these bacteria are the dominant bacteria in dental plaque and associated with dental caries. ${ }^{3}$

The problems that can arise due to the accumulation of denture plaque are denture stomatitis, oral malodour, the source of infection, and hygiene. ${ }^{3}$ Therefore, 
denture cleaning must be considered by denture wearers. Two methods commonly used in cleaning denture are the mechanical technique and chemical technique. Mechanical technique is done using toothbrush and ultrasonic. Chemical technique is done by soaking the denture in a disinfectant solution, such as peroxide alkaline, hypochlorite alkali, chlorhexidine, sodium hypochlorite, enzymes and herb. ${ }^{4}$

One of the herbal ingredients widely used in traditional medicine is a roselle (Hibiscus sabdariffa L.). Roselle flowers are commonly used by Indonesian people as a healthy drink. Leaves or petals of rosella boiled with water is useful as laxative urine and stimulates the release of bile from the liver, lowers blood pressure, reduces blood viscosity, and increases intestinal peristalsis. Roselle plant has been known as an anticonvulsant or antispasmodic, anthelmintic, and as an antibacterial. ${ }^{5}$ Some types of bacteria that are still sensitive to roselle is Bacillus spp., and S.aureus. ${ }^{6}$

Moreover, roselle has also been proven to be effective as an antifungal. Numerous studies have shown that rosella flower extract can inhibit the growth of C.albicans, which is one of denture plaque microorganisms. Research conducted by Maruapey ${ }^{3}$ showed that denture cleanser toothpaste made from roselle is effective in inhibiting plaque formation, growth of bacteria and Candida albicans. ${ }^{4}$ However, effectiveness period of roselle toothpaste preparation is still not known.

This is why this study examines the effectiveness period of roselle (Hibiscussabdariffa L.) denture cleansers toothpaste ininhibiting plaque formation and the growth of bacteria and C.albicans on the denture.

\section{Materials and Methods}

This study is a clinical and laboratory experiment, with pre- and post-test design which includes five samples at each data collection (registration number of ethical clearance: UH14020076). Samples were full acrylic removable denture users, have used dentures for at least 2 weeks, had no history of systemic disease and willing to participate in research with a signed informed consent.

Roselle denture cleanser toothpaste with concentration of $2.5 \%$ was prepared three months before the study began. At the time of data collection removable denture was rinsed with running water to clean the debris. Smear was performed on the surface of the palatal and intaglio plaque was examined using disclosing tablets (Biodinamica) and assessment of plaque scores used Modified Quigley Hein index. Then, the dentures were cleaned with roselle toothpaste. Smears and plaque score assessment were carried out in the same way as before cleaning.

Before and after cleaning smears were sent to the Laboratory of Microbiology, Faculty of Medicine,
Hasanuddin University for examining the number of colonies of bacteria and C.albicans. Examination was repeated at month 6 and 9 after the paste was made.

The collected data is analyzed statistically using statistical tests. Since this research is a comparative analytical categorical pair, statistical test used is marginal homogeneity or Wilcoxon test. Then further testing employed Friedman two ways sample related test to examine the relationship between each testing time. Confidence level used is $95 \%$ or the value of $p$ $<0.05$.

\section{Result}

Table 1. Bacterial colonization on a fulldenture acrylic before and after cleaning with roselle toothpaste at $3^{\text {rd }}, 6^{\text {th }}$, and $9^{\text {th }}$

\begin{tabular}{|c|c|c|c|}
\hline \multirow{2}{*}{ Month } & \multicolumn{2}{|c|}{ Bacteria colonization ( $\mathrm{CFU}$ ) } & \multirow[t]{2}{*}{$\mathbf{P}$} \\
\hline & $\begin{array}{c}\text { Pre-test (Mean } \\
\pm \text { Sd) }\end{array}$ & $\begin{array}{c}\text { Post-test } \\
(\text { Mean } \pm \text { Sd })\end{array}$ & \\
\hline 3 & $129.8 \pm 65.94$ & $61 \pm 58.29$ & 0.043 \\
\hline 6 & $48.2 \pm 83.34$ & $26.8 \pm 47.97$ & 0.068 \\
\hline 9 & $175 \pm 30.9$ & $105 \pm 25.67$ & 0.043 \\
\hline
\end{tabular}

CFU

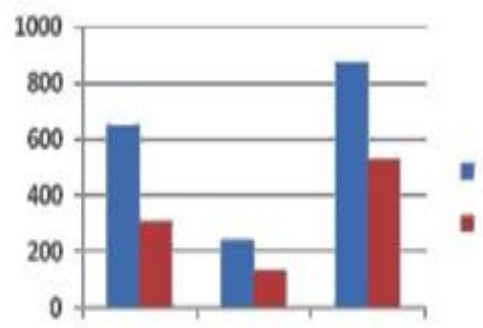

Figure 1. Comparison of bacterial colonizationbefore and after application of paste roselle at any time of testing

Table 2. Candida albicanscolonization on a fulldenture acrylic before and after cleaning with roselle toothpaste at

\begin{tabular}{|c|c|c|c|}
\hline \multirow{2}{*}{ Month } & \multicolumn{2}{|c|}{$\begin{array}{l}\text { Candida albicans } \\
\text { colonization } \\
(\mathrm{CFU})\end{array}$} & \multirow{2}{*}{$\mathbf{P}$} \\
\hline & $\begin{array}{c}\text { Pre-test } \\
(\text { Mean } \pm \text { Sd })\end{array}$ & $\begin{array}{c}\text { Post-test } \\
(\text { Mean } \pm \text { Sd })\end{array}$ & \\
\hline 3 & $53 \pm 84.96$ & $11.2 \pm 22.87$ & 0.109 \\
\hline 6 & $11.2 \pm 23.94$ & $4.6 \pm 10.29$ & 0.068 \\
\hline 9 & $10.8 \pm 14.94$ & $2.6 \pm 3.58$ & 0.180 \\
\hline
\end{tabular}

Source: prime data $\alpha<0,05$ 


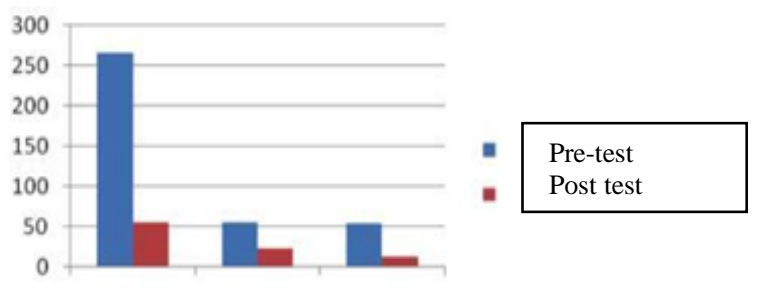

Figure 2. Comparison of Candida albicanscolonization before and after application of roselle toothpaste at any time of testing

Table 3. Plaque score on a full denture acrylic beforeand after cleaning with rosella toothpaste at $3^{\text {rd }}$, $6^{\text {th }}$, and $9^{\text {th }}$ month

\begin{tabular}{cccc}
\hline Month & \multicolumn{2}{c}{ Plaque Score } & \\
& $\begin{array}{c}\text { Pre-test } \\
(\text { Mean } \pm \text { Sd })\end{array}$ & $\begin{array}{c}\text { Post-test } \\
(\text { Mean } \pm \text { Sd })\end{array}$ & \\
\hline 3 & $2.4 \pm 0.55$ & $1.2 \pm 0.45$ & 0.034 \\
6 & $3 \pm 1.00$ & $1.6 \pm 0.89$ & 0.038 \\
9 & $2.8 \pm 0.84$ & $1.4 \pm 0.55$ & 0.038 \\
\hline
\end{tabular}

Source: prime data $\alpha<0,05$

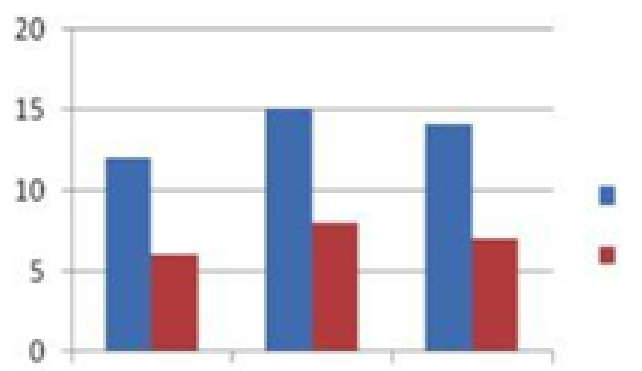

Figure 3. Comparison of plaque score before andafter application of rosella toothpaste at any time of testing

Table 1 shows the results from Wilcoxon statistical test with $\mathrm{p}<0.05$ in the 3rd month which means that there was a significantly difference in the effectiveness of roselle toothpaste in inhibiting the growth of bacteria with a value of $p=0.043$. In the 6th month, $p$ value was $>0.05$, which means there was no significant difference in the effectiveness of Roselle toothpaste in inhibiting the growth of bacteria with a $\mathrm{p}$ value $=0.068$. In $9^{\text {th }}$ month, $\mathrm{p}$ value $<0.05$, which means there was a significant difference in inhibiting the growth of bacteria with a $\mathrm{p}$ value $=0.043$.

Table 2 shows the results obtained by the Wilcoxon statistical test with a $\mathrm{p}$ value $>0.05$ in the $3 \mathrm{rd}, 6 \mathrm{th}$, and 9th month which means that there is no significant difference in the effectiveness of the roselle toothpaste in inhibiting the growth of C.albicans with a $\mathrm{p}$ value $=$ 0.109 in 3rd, $p=0.68$ in 6th, $p=0.180$ in 9th month.

Table 3 shows the results obtained by the Wilcoxon statistical test with a $\mathrm{P}$ value $<0.05$ in the $3 \mathrm{rd}$, 6th, and 9th month which means that there are differences in effectiveness of roselle toothpaste in inhibiting the growth plaque with $\mathrm{p}$ value $=0.034$ in the $3 \mathrm{rd}$ month, the value of $\mathrm{P}=0.038$ at 6 th months, and the value of $\mathrm{P}$ $=0.38$ in 9 th month.

\section{Discussion}

Maruapey stated that roselle paste at concentration $2.5 \%$ was already effective in inhibiting the growth of bacteria, C.albicans and plaque formation.3 On this basis, further experiment needs to be done to determine the effect of storage time on the effectiveness roselle toothpasta. This study shows that the roselle paste stored for 3 months was effective in inhibiting the growth of bacteria and plaque formation $(\mathrm{P}<0.05)$, but there was decreasing effectiveness in inhibiting the growth of C.albicans

Antifungal and antibacterial effect produced by rosella flower petals in this study are believed to be produced by rosella flower petals (Hibicscus sabdariffa L) which contains several flavonoids (anthocyanins, gossypeptin (hexahydroxyflavone) 3-glucoside, flavonol glucoside hibiscritin, flavonoids gossypeptin, delphinidine 3monoglucoside, cyanidin 3-monoglucoside), vitamin $\mathrm{C}$, protein, carbohydrate, beta-carotene and antioxidants. In this study, the extraction was done with maceration method using ethanol $97 \%$ but there is no specific separation for flavonoids substances. Flavonoids are groups of phenolic compounds found in the nature. These compounds are colored red, purple and blue and in plants is colored yellow. ${ }^{6.7}$

Most flavonoids are found in the form of glycosides. The flavonoids units are bound to a sugar. Glycoside is a combination between a sugar and an alcohol linked to each other through a glycoside bond. In principle, the glycoside bond is formed when a hydroxyl group of the alcohol is on the carbonyl group of the sugar, like the addition of alcohol to aldehyde catalyzed by acid which produces an acetal. ${ }^{7}$

Flavonoids function by means of protein denaturation by increasing the permeability of cell membranes. Denaturation of proteins leads to disruption in the formation of cells that alter the composition of the protein component. Disrupted cell membrane function can lead to disruption in the formation of the cell, resulting in cell damage of Candida and bacteria. It causes the death of Candida and bacteria, which is consistent with Jawetz studies. Protein denaturation can damage the cells permanently. Following Alcamo's research, flavonoids are phenolic compounds which have fungi static or fungicidal effect. Harborne reported that flavonoids are able to form a complex compound 
with the protein through a hydrogen bonding, and thus the protein deposition can inhibit the growth of plaque. ${ }^{9}$

In month 3, Roselle toothpaste was effective in inhibiting the growth of bacteria $(p<0.05)$. In 6 th month, the effectiveness of paste in inhibiting the growth of bacteria has decreased. Decreasing number of bacterial colonies before and after application of paste still occurred, but did not show a statistically significant difference. But in the 9th month, the paste was effective in inhibiting the growth of bacteria. Total $\mathrm{P}$ value test with Friedman's two ways test showed no significant difference in effectiveness roselle toothpaste in inhibiting bacterial growth.

The effectiveness test of rosella toothpaste in inhibiting the growth of C.albicans found that there was decreasing in effectiveness of toothpaste from the 3rd month. Further testing with Friedman's two ways test showed no significant difference in effectiveness of roselle paste in inhibiting the growth of C.albicans between each testing time.

Decreasing ability of roselle paste to inhibit the growth bacteria is contrary to Tanjong and Dharmautama. ${ }^{10}$ They showed that $40 \%$ of roselle extract is comparable to $200 \mathrm{mg}$ ketaconazole. This difference may be because Tanjong only took a swab for culture of C.albicans from samples who have been wearing dentures for 25 years.

Knezović-Zlatarić et al stated that the alveolar bone resorption in the first year of full denture wearers occurs progresifly. ${ }^{11}$ Thus, dentures will not fit with the mucosal tissue. This is led to increasing colonization of bacteria and Candida. ${ }^{12}$

The difference between Tanjong and Dharmautama, and this study can be due to the limitation of the study criteria in the sample. Most of the samples included in this study have been wearing dentures in a long period; and some others have recently undergone denture insertion procedure (at least 2 weeks). Colonization of bacteria and Candida on the dentures which have been used for a long period is different than 2-week-old dentures.

Roselle toothpaste effectiveness in inhibiting plaque formation still appeared until the month 9th. When Friedman's two ways sample related test was performed, it shows that effectiveness of roselle toothpaste remains the same in inhibiting plaque formation between each testing time. Paste remains effective in inhibiting plaque formation. Plaque formation cannot be prevented, even on new dentures. Plaque formation will occur within a few minutes after professionally cleaning or just inserted. Within 2 days, plaque has been completely formed. ${ }^{12}$ This can cause the difference in the effectiveness of roselle toothpaste in inhibiting the growth of bacteria and C.albicans with its effectiveness in inhibiting plaque formation.

\section{Conclusion}

There is no effect of storage time on the roselle denture cleanser toothpaste in inhibiting plaque formation on acrylic denture base; but there is effect of storage time of toothpaste rosella denture cleanser on growth inhibition of bacteria and C.albicans on acrylic denture base.

\section{References}

1. Carlsson GE, Omar R. Trends in prosthodontic. Med Princ Pract. 2006;15:167-79

2. Rathee M, Hooda A, Ghalaut P. Denture hygiene in geriatric persons. Int J Geriatr Gerontol. 2010; 6: 1

3. Maruapey AM. Efektivitas penggunaan pasta pembersih gigitiruan bunga rosella (Hibiscussabdariffa L.) dalam menghambatpembentukan plak pada gigitiruan. [Tesis]. Makassar: Program Pendidikan Dokter Gigi Spesialis Prostodonsia Fakultas Kedokteran Gigi Unhas; 2013. p. $43-58$

4. Widyanto PS, Nelistya A. Rosella. Jakarta: Penebar Surabaya; 2008

5. Elmanama AA. Alyazji AA. Abu Gheneima NA. Antibacterial, antifungal and synergistic effect of Lawsonia inermis, Punicagranatum and Hibiscus sabdariffa. AnnAlquds Med.2011; 7:33-41.

6. Sherley, Dwiyatmoko B. Suganda AG. Rosella Hibiscus Sabdarifa L. Serial data obat terkini tumbuhan obat. Jakarta: Direktorat Obat Asli Indonesia, Badan Pengawasan Obat dan Makanan RI; 2010 p.1-13

7. Lenny S. Senyawa flavonoid, fenilpropanoida dan alkaloid. Medan: Karya ilmiah, Departemen Kimia USU, 2006.

8. Jawetz EM. Review of medical microbiology. 16th Ed. San Fransisco: Longo Medical Pub.; 1986.p. 143-8, $297-$

9. Harbone JB. Metode fitokimia. ( $4^{\text {th }}$ ed.). Bandung: Penerbit ITB Press; 1987. p. 102,151

10. Tanjong A, Dharmautama M. Pengaruh konsentrasi ekstrak bunga rosella (Hibiscussabdarifa L) terhadap koloni Candida albicans yang terdapat pada platgigitiruan;2011.p.76

11. Knezović-Zlatarić D, Čelebić A, Lazić B. Resorptive changes of maxillary and mandibular bone structures in removable denture wearers. Acta Stomatol Croat. 2002; 6 (2): 261-5

12. Nield-Gehrig JS. Dental plaque biofilms. Available from: http://www.dentalcarestamford.com/pdf/

Denta\%20Plaque\%20Biofilms.pdf. [Accessed on: November 3rd, 2014] 